Global Conferences Series:

Social Sciences, Education and Humanities (GCSSSEH), Volume 6, 2020

International Conference Fakultas Tarbiyah dan Keguruan Universitas Islam Negeri Imam Bonjol Padang (ICFTKUINIBP) 2020

DOI: https://doi.org/10.32698/icftk412

\title{
The Role of ICT in the Teaching of Productive Skills in English During Covid-19: Students' Perceptions and Obstacles
}

\author{
Besral \\ Faculty of Islamic Education and Teacher universitas Islam Negeri Imam Bonjol, Padang, Indonesia \\ E-mail: besral@uinib.ac.id
}

\begin{abstract}
English as a Foreign Language (EFL) teachers believe that students cannot reach a good level of fluency unless they speak and write English with less difficulty and more spontaneity. The current study seek to uncover students' perceptions and obstacles in learning productive skill as promoted in Concept Mapping technique. A short and brief notes of students' impressions of up to the third meeting of English course were taken as the primary data for the study. They were verified and categorized into sub themes allowing the researcher to count and analyze. The findings showed that by using ICT, (1) Classroom atmospheres were very positive; (2) Most students understood the lesson, although few students had troubles to understand and initiate the tasks; (3) Small numbers of students had bad connection, and therefore claimed that Google Classroom was not effective. It can be concluded that the use of ICT in EFL learning for this group of students should be expanded because of promising ideas behind it.
\end{abstract}

Keywords: Information communicationtechnology, productive skill, concept-mapping

\section{INTRODUCTION}

Massive integration of technology into educational system especially in the pandemic of Covid-19 era is not a new issue in English as Foreign Language (EFL) learning. This is so because, as Richards and Renandya (2002: 368) cited in Warschauer (1995b. p. xv0, that 'technology is developing so rapidly that it can often be difficult or even overwhelming to harness somewhat like trying to get a drink of water from a gushing fire hydrant'. In fact, teachers have been very familiar with using online communication in the language classroom since the 1980s (Richards and Renandya, 2002: 368). What makes it so astonished in our current teaching today is that teachers, on the first had, rarely or do not implement modern technology to the maximum level in their classes because of many reasons. On the other hand, students were lack training on the use of digital tools because they were not used to do it. A part from the controversial issues of why less teachers employ ICT in today's classes, this study highlighted how technology helps the instructor to achieve the learning goals in the mid of Covid-19 pandemic within various obstacles faced by the students around Sumatra island. The current study focuses on particular reference to subject 'English' consisting of 2 credit units for the Undergraduate English students at State Islamic University, Imam Bonjol Padang.

The main purposes of this study were to find out (1) specific classroom atmospheres in related to technology employment; (2) quality of learning system management; and (3) students' obstacle in following or taking part in online classroom. These purposes are very significant in the pandemic era for several reasons. First of all, the faculty members have relatively short experience in handling online classes, hence, no comprehensive evaluation or assessment were made to indicate success or failures of the program. Second, although most EFL teachers or lecturers are well informed in the roles of ICT, very few of them had qualified or thorough expertise in their classroom teachings. In fact, with the development of ICT technology, no one can deny that in some respects, students are well knowledgeable than lecturers. With this in mind, one can assume or theorize that online learning should give much more beneficial to the students.

The design of EFL and ICT based is in line with the content of instruction or syllabus, learner roles, teacher roles, and instructional materials and their types and functions (Kumaravadivelu, 2006: 86). Adopting

Copyright $@ 2020$, the Authors. Published by Redwhite Press.

Page | 124

This is an open access article under the CC BY-NC license

(http://creativecommons.org/licenses/by-nc/4.0). 
theories in Second Language Acquisition (SLA), Renandya (2020) proposes five key issues in related to EFL principle and technology such as input, noticing, frequency effects, social interaction, and motivation. For him, L2 acquisition happens when students receive massive input which are comprehensible and compelling. Since Islamic University Students (IUS) is formatted to master Islamic studies and aspects related to Islamic teaching, the primary input must be taken from the Quran and Hadist or Prophet Tradition. These materials have been primarily published in book forms and later are transformed into internet through digital form as well as in Youtube. Even though they are accessible, some of them must be adapted to satisfy the existing needs. They are compelling in the sense that they require multiple skills from the lower to higher thinking skills to proceed it.

The second principle, noticing, is that input alone is not enough. Students need to notice the language features. It does not necessarily means that teacher pour all grammatical structure to the students as presented in the textbook of grammars. The Communicative Language Teaching (CLT) principle reminds that it must be taught in context, give them as they need or relevant to the materials, and teach them explicitly. Language features should be mastered by the students at the same time when they recognize purpose of the communication such as to describe, explain, classify, give reason, categorize, etc.

According to Renandya (2020), frequency effects lies on the fact that frequency of encounter determines what gets learned. 'Again and Again' principle is a must because: (1) they haven't had enough practice in saying these sentences; (2) the teacher has not done a good job teaching them; (3) they are not very smart kids; (4) they rely too much on their mother tongue; and (5) they haven't seen nor heard enough English.

Another key factor for successful EFL teaching is that 'Social Interaction'. It has already been a common knowledge today that social interaction is human basic need, therefore, English is taught to fulfill communicative needs. To achieve this purpose, teachers have to increase amount of language use. By social interaction, then, students' fluency in English can be realized.

Finally, students' type and level of motivation determine the mastery of language being studied. We should believe that 'No motivation, No learning'. But, we should also admit that 'teaching can be motivating'. In effects, teacher plays a key role.

Based on the essential factors as outlined above, the question now arises as how to put such the principles into online learning. Warschauer and Fawn in Richards and Renandya (2002: 368-373) suggest the following things to consider before implementing the so called online learning. First of all, consider carefully the Goals. It is believed that it creates optimal conditions for learning to write, since it provides an authentic audience for written communication. It is also believed that it can increase students' motivation as well as the belief that learning computer skills is essential to students' future success. Based on these believes, the writer is positive that these students (first semester, graduated from different high schools which are mostly from Boarding schools or Islamic Senior High school in Sumatra island, in the range of elementary and intermediate proficiency level) would be able to: " $a$. Read and understand the texts written in English; $b$. Reconstruct the texts into Concept-Mapping and short or simple paragraph; and c. Motivate them to use computer". (Curriculum and Design for Learning, 2018)

Second is integration, namely to consider what kinds of activities and projects are well integrated into the course curriculum as a whole. To fulfill this requirement, the writer planned to provide students with 8 to 10 reading passages about Islam and International as well as target Cultures that are essential to their future careers. Each passages serve as inputs for learning that explore lexical and syntactic structures leading to discourse competence. Students then are guided to conceptualize their understanding of the text by reconstructing such a concept-mapping. This is quite a difficult work at first, but by the help of internet or computer tools, they are expected to show their emotions, belief, or imagination using the images in the computer.

Third, Don't Underestimate the Complexity. EFL Teachers should put in mind that, although we have had students who are quite experienced with computers, Warschauer (1995b) claims..'we have also had students who had seldom used a computer; lacked basic knowledge such as how to operate a mouse or open a folder; and lacked the vocabulary, reading, and listening skills to follow instructions for using the computer'.

The fourth guideline for the teachers is Provide Necessary Support. It is suggested that in case of complexities arise in Internet usages, teachers should support students' difficulties in many forms such as: creating detailed handouts that students can refer to when class is finished and the teacher's personal help is not accessible, etc. Selecting the most appropriate textbook for Islamic Teaching is almost impossible for there at least two disciplines mostly required such as expertise in Islamic teaching and EFL teaching methodology. The difficulty for this task lies in the following requirements as stated in Barnard and Dorothy Zemach (2003) that prospective writer should have, among other things: 
An acceptable linguistic knowledge of the target language; general teaching experience; teaching experience in the relevant specialism; some degree of knowledge of the relevant specialism. p. 313.

Finally, as suggested by Warschauer (1995b), involve students in Decisions. According to Richrads and Renandya (2002), the concept of a learner-centered curriculum (Nunan, 1988) predates, and has broader significance than the Internet-enhanced classroom. Thus, involving students in determining the class direction does not imply a passive role for teachers.

\section{METHOD}

A number of sixty freshmen English students studying English course at English Tadris Department were the subjects of this study. They were spreading in two parallel class, A and B. So far, there is no way of telling why they were classified so. Fortunately, the researcher has full access to both classes. Without having any tendency, class A (30 students) was taken as sample for the current study. The original instrument for this study was based on 'Students' Impressions on the Current Meetings' which were written and posted to the researcher. These impressions were categorized into several themes and broken into several items for easy counting. Students' impressions were later put into percentages. Another data were taken from interviews, voicing similar expressions to the first type, but were more directed to conceptmapping employment. Both data were taken in first and fourth meeting through Google Classroom.

The calculation of percentages for items analysis were based on students' responses and response of above sixty percent is considered significant. Data from interviews were cited to provide further analysis, especially in the implementation of Concept-mapping technique. Both of these data can not be used to generate the findings, as the program was still under going, meanwhile, the study was not directed to improve the students' competence.

\section{RESULTS AND DISCUSSION}

Presented below is data derived from students' impression which covers three major points such as classroom atmospheres, quality of learning system management, and obstacles faced by the students.

Table 1. Classroom Atmosphere

\begin{tabular}{|c|c|c|}
\hline No & Aspects & Percentages \\
\hline 1 & I understand the lessons & 24 \\
\hline 2 & I don't understand the assignment & 48 \\
\hline 3 & I don't know how to start & 24 \\
\hline 4 & I like the Lecturer's teaching technique & $72 *$ \\
\hline 5 & The class is fun and full of enjoyment & $72 *$ \\
\hline 6 & This kind of learning is really motivating & $72 *$ \\
\hline 7 & The lecturer is helpful & $62 *$ \\
\hline 8 & Google Classroom is not effective & 24 \\
\hline 9 & The connection in my place is very poor & 28 \\
\hline
\end{tabular}

As already mentioned before that these data pictured the ongoing process of online English learning from $2^{\text {nd }}$ to $4^{\text {th }}$ meeting. Seventy-six (76) percents of the students did not understand the lesson, while 48 percents did not understand the assignment. Further more, 24 percents did not know how to start the assignment. What do these data mean? First of all, the class was dominated by other 24 students. They asked the materials that they did not know about, clarified the teacher's comments, and admitted their mistakes as expressed by Ayu (False Name).

" The impression of learning English with Mr. Besral today, Tuesday, September 29 2020. the impression is exciting and challenging, because you teach a good way and can also involve students to be active in discussions or answering questions. And we can understand what you explain and even though there are some materials that can be said that we don't understand a bit, but God willing, we can repeat or continue to practice so that we can understand the material taught by you”. (\#2)

In almost similar way Betri (False Name), added:

"The impression of studying with Mr. Besral was that I was a little afraid because the task was difficult. Then I was confused about where to start, I didn't want to fail in college but the assignment was difficult. When answering questions I don't know how to answering the questions". 
It was evidenced from these data that the classroom atmosphere was not silent or frozen, rather it was full of fun and happiness, as seen in the following data.

\section{Quality of Learning System Management}

As depicted in the data above, students (72\%) liked the technique presented by the teacher, the class was full of fun and enjoyment (72\%), because this kind of learning was motivating (72\%). Candra (False Name) commented that:

The first and first class meetings with you according to my imagination will trade off but it turns out that all of that is wrong, if we are able to understand what you explain, learning with you is cool. but what I regret is that my cellphone cannot open the material that the father gave me so I have difficulty in giving responses on gc ...I'm sorry sir

Desi (False Name) adde+d that:

" KesanbelajarbahasaInggris dg pak. Besral yaitudi awal saya merasa kesulitan dikarenakan saya tidak mengerti dengan apa yang bapaktu gaskan kepada kami, dantugas yang datang bertubi" dana danya berlain anpenda patdengant emansesama membuat saya tidak paham Dan tidak tau harus memulai mengerja kantugas darimana,.. So, I hope you could explain in more detail how we should proceed, and allow us to ask questions. Agar kami tida ksalah dalam mengerjakan tugas yang bapak berikan, Bapakbaik, dan bapak very excited dalam mengajar kami”,

\section{Obstacles}

The main obstacles for the students' learning was that dealing with unsatisfied connection in the their places (28\%), hence, blamed Google Classroom (24\%). though not significant in number, poor connection disturb classroom climates in which teacher have to wait for the appropriate responses.

Emi (False Name) was quite unhappy when she said:

$$
\text { “ klahpak, }
$$

kesansayabelajardenganbapakadalahbelajardenganbapakitucukupmenyenangkankaren abapakmeresponsemuaapa yang kami jawabwalaupunitukadangjawaban kami salahdanbapakjugamemberikanarahankepada kami, Tapi yang sayakeluhkandisiniadalahsayakurangpahampakjikahanyamenggunakanaplikasi $\quad G C$ sebab kadang2 jaringannyanyangkutdankomentarnya pun kadangjadisepi tiba2 pak, untukpenjelasannyajugakepotongsamakomentar teman2 lain nya, itumembuatsayabingungpak. Dan untuktugasjugapakmohon di jelaskandenganbahasaindonesiapak, maafkan kami yang belumpasihdalamberbahasainggris, karena kami jugabarubelajarpakhehe, Agar tugas kami bisa di kerjakan"

The temporary achievement of the above findings were based on efforts as suggested by previous theories or experiences in the field such as those of Renandya and Warschauer (1995b) who maintain that successful online learning depends on the clarity of goals of teaching. Understanding the text written English and reconstructing the text into Concept-mapping are such ideal goals that might be achieved through carefully preparation of materials by using ICT. The selected materials for 8 to ten meetings have been set up and they were posted subsequently in the Google Classroom to include:

Table 2. Student Posted Subsequently in the Google Classroom

\begin{tabular}{lcc}
\hline Title & Genre & Speech Act \\
\hline \#1 Pillars of Islam & descriptive & describing \\
\#2 Islam and the State & recount & Comparing things \\
\#3 The Meaning of Islam & Analytical expo & Critical analysis \\
\#4 How the Egyptians Used to Bury Their & procedures & Resembling concepts \\
Deads & & \\
\#5 Religion and Culture & Analytical expo & arguing \\
\#6 Science and the Quran & discussion & arguing \\
\#7 Approaches to Islamic Law Studies & discussion & arguing \\
\#8 SyayyidQutb & recount & discussing \\
\hline
\end{tabular}


As each topic or title are posted earlier in the introduction (first meeting), students may have get prepared with all of the materials and begin to do the required tasks. These tasks include understanding and making a concept-mapping. In understanding the text, students are required to do the following activity such as identifying topic, topic sentence, main idea, word reference, and inferential skills. The realization of this activity is conducted through 'Quick Test' or Quiz as follows:

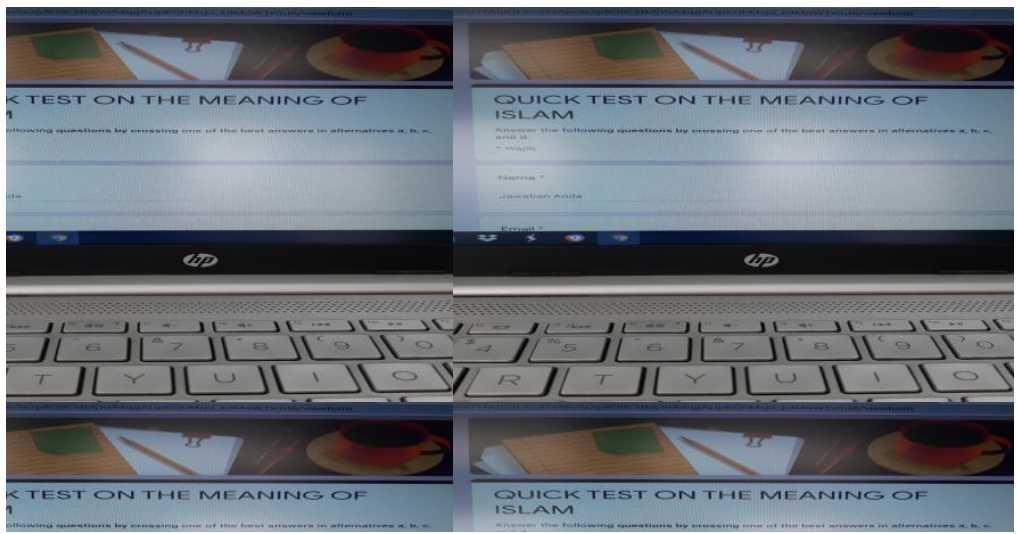

Gambar 1. Quick Test' or Quiz

In constructing the text, students are first introduced to definition, use, and function of concept mapping in developing critical thinking skill while improving speaking skills. Later, they were trained to make it and practice saying or explaining their concepts. Finally, when thing is fine, they were instructed to record their presentation and post it to Goggle Class. Here is complete guideline as posted in GC. (1) Pick or select all of the essential concepts in the text; (2) Arrange or place the concepts vertically or horizontally, the more important the concepts, the higher position they have or closer to the center; (3) Each concepts should be given a special image. Some concepts may have equal image, depending on the message to be reflected; (4) Each concepts must be connected with arrows. Students have to be able to explain such the relationships. (5) When the concept map is ready, students are trained to read or explain their concept mappings. While they are doing it, they should record and post it to the class.

All of the above activities are done with the help of computer, and this is meant to motivate students to use the computer (point c). sample of concept mapping is presented below:

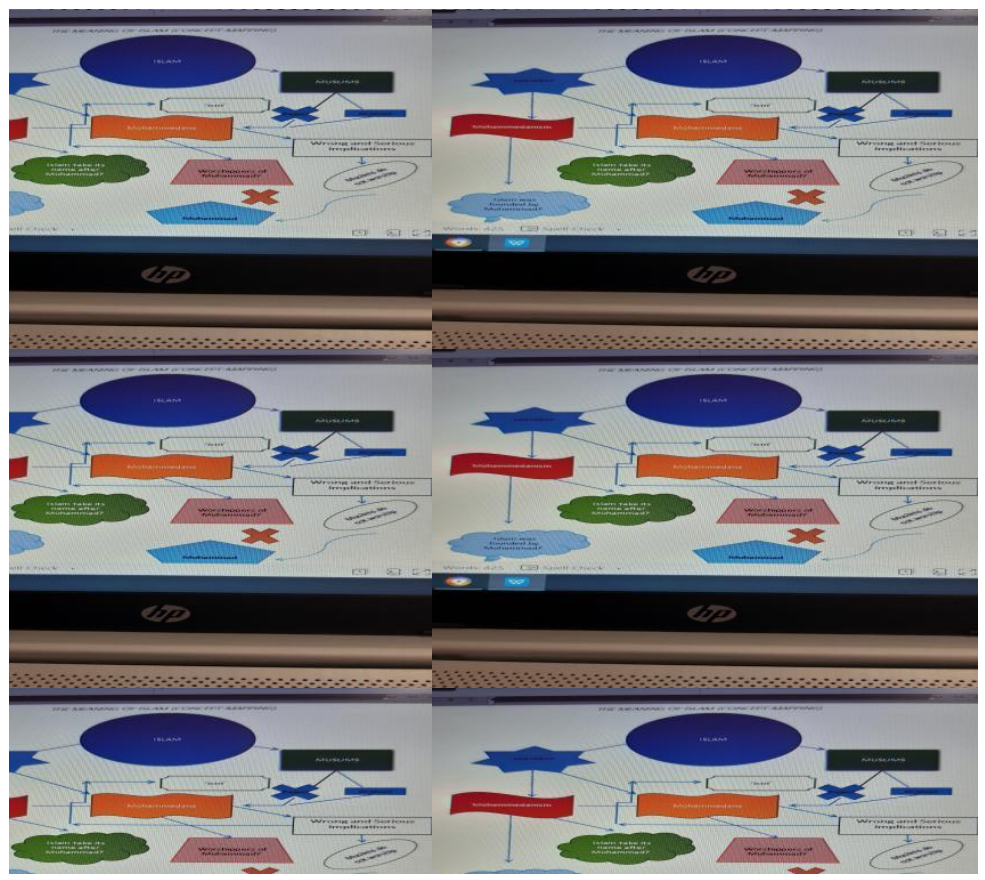

Tabel 2. Sample of Concept Mapping 
Students' products of learning in the forms of concept mapping and record of their presentation are scored to determine their achievement of the unit lesson. All of these activities are done quite easily because of the availability of this tool in the GC as seen below.

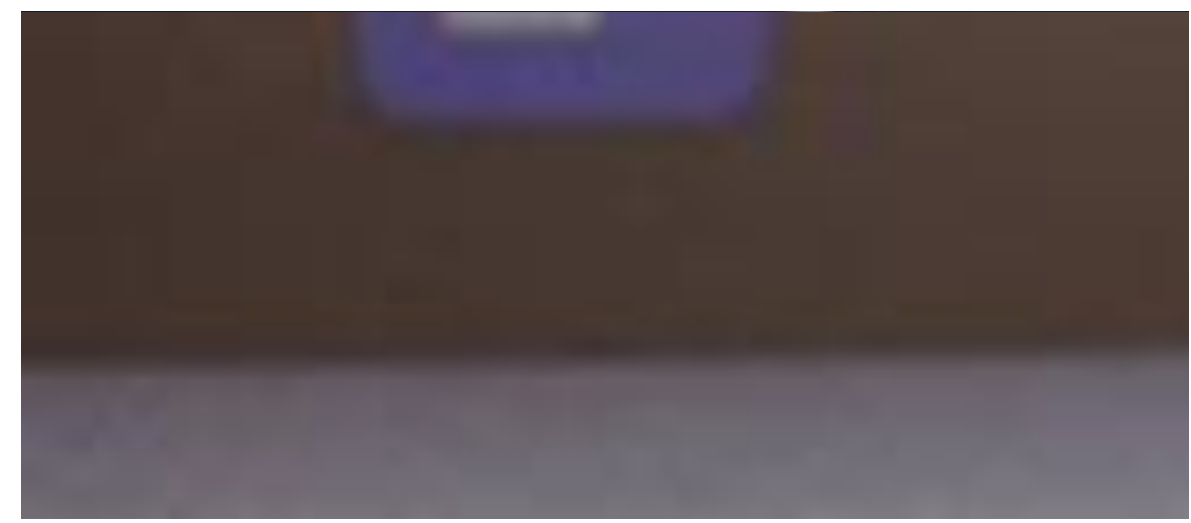

Gamber 3. The Availability of Concept Mapping and Record in the GC

The ideal score was hard for them to achieve especially in the first two meetings because they had troubles to understand the instruction and did not know how to proceed or send them to the lecturer. To ease such difficulties, therefore, the teacher or lecturer has to provide them with learning assistance and for this purpose, personal and group Watch Up are activated for discussions.

Another crucial factor in EFL learning is that how to assist students' language in terms of grammar and vocabulary. Although debates continue to exist in the realm of Communicative Language Teaching (CLT) principles (Fotos, 2002; Ellis, 2002; Salies, 1998; Musthafa, 2001 to name a few), the writer prefers to consider 'implicit structure-based tasks' following grammar instruction (Hee, Seung, et. al., 2005) as it facilitates learner acquisition (Ellis, 2002).

\section{CONCLUSIONS}

This paper has discussed the role of ICT in motivating freshmen English students while introducing the use of concept-mapping for better understanding of texts written English. While the process is still under going, there is no evidence to claim the success or failures of this particular EFL teaching in this faculty, except students' impressions that are promising to some extents. Referring to the previous theories, it is important to put into minds that the linguistic nature of online communication is desirable for promoting language learning. More over, online learning increases students' motivation, as well as skills for future success.

These findings are particularly important for beginner teachers or lecturers in the field of TEFL where internet connection is possible to direct online learning. The same application will continue to exist, but building students' capacity to be creative while developing their English skills deserves to be much more valuable than just curing the present spread of Covid-19.

\section{REFERENCES}

Barnard, Roger and Dorothy Zemah. (2003). Materials for Specific Purposes. In Developing materials for language teaching. Tomlinson B. (Ed). Continuum. The Tower Building, 11 York Road, London SE 1 $7 \mathrm{NX}$.

Ellis, R. (2002). Methodological options in grammar teaching materials.In Hinkel, Eli \&Fotos, Sandra (Eds), New Perspectives on Grammar Teaching in Second Language Classrooms (pp. 155-180). New Jersey: Lawrence Erlbaum Associates, Publishers Mahwah.

Fotos, Sandra. (2002). Structure-based interactive tasks for the EFL grammar learner.In Hinkel\&Fotos (Eds), New Perspectives on Grammar Teaching in Second Language Classrooms. New Jersey: Lawrence Erlbaum Associates, Publishers Mahwah.

Hee, Seung. (2005). Teaching English Grammar in a Communicative Approach. EFL Journal Vol.3 No.2. Kumaravadivelu, B. (2006). Understanding Language Teaching.From Method to Postmethod. Lawrence Erlbaum Associates, Inc..Publishers, New Jersey 07430. 
Musthafa, B. (2001). Communicative language teaching in Indonesia: Issues of theoretical assumptions and challenges in the classroom practice. Eric Document:

Richards, JC. and Willy A. Renandya. (Ed). (2002). Methodology in Language Teaching. An Anthology of Current Practice. Cambridge University Press

Richards, JC. and Willy A. Renandya. (Ed). (2020).SLA Principle and Technology. Presented in $8^{\text {th }}$ Elite International Conference: Technology Enhanced ELT in the Post Pandemic Era (Zoom meeting, Augt. 23-24, 2020)

Salies, T.G. (1998). Pronoun case: Teaching grammar within a communicative paradigm. Eric Document: 424-767

Warschauer, M. (Ed).(1995.b).Virtual connections: Online activities and projects for net-working languahe learners. Honolulu: University of Hawaii, Second Language Teaching and Curriculum Center. 